\title{
乳幼坚期の聴覚活用と言語習得
}

\author{
中村 公枝
}

\begin{abstract}
要＼cjkstart約：乳幼児期の聴覚活用と言語習得について以下の観点から考察を加えた. (1)聴覚・コ ミュニケーション・言語習得, (2)聴覚活用と言語習得の関係, (3)聴覚障害乳幼児の音声言語習 得上の課題と対応. 聴覚障害児の聴覚活用とは，コミュニケーション場面での意味ある聴覚的 経験を通して「能動的な聴くシステム」を形成することである．そのための必要事項として， (1)前言語的コミュニケーション, (2)語彙習得, (3)文法習得, (4)リテラシーと談話理解の 4 つを 取り上げ，そこでの課題と対応を明らかにした。なかでも音声言語習得に必要な情報処理とし て統語構造処理の重要性について述べた。また最大限の聴覚活用をするために視覚を活用する ことの意義と重要性についても言及した。
\end{abstract}

索引用語：聴覚障害乳幼児，聴覚活用，コミュニケーション，言語習得

\section{Use of the Auditory Modality and Language Acquisition}

\section{Kimie Nakamura}

\begin{abstract}
In this paper we discuss use of the auditory modality and language acquisition in hearing-impaired young children, focusing on the following aspects: 1) hearing/communication/language acquisition; 2) the relationship between use of the auditory modality and language acquisition; 3 ) issues inherent to the process of oral language acquisition by hearing-impaired young children, and responses to those issues.

Inducing hearing-impaired children to use the auditory modality consists of having them forge "an active listening system via the auditory modality" through meaningful experiences in vocal communication. To forge such a system, the following conditions are necessary: 1) prelinguistic communication, 2) vocabulary growth, 3) acquisition of grammatical skills, 4) literacy and contextual understanding of conversation.

In discussing the development of the foregoing "system" for acquiring oral language, we note the importance of ability to perceive syntactic construction in speech. We also stress the significance of using visual cues in order to achieve maximum use of the auditory modality.
\end{abstract}

Key words: hearing-impaired young children, use of the auditory modality, communication, language acquisition

国立身体障害者リハビリテーションセンター学院：テ359-8555 埼玉県所沢市並木 4-1

National Rehabilitation Center for Persons with Disabilities, College: 1, Namiki 4-chome, Tokorozawa City, Saitama Prefecture 359-8555

2007 年 1 月 31 日受理 


\section{はじめに}

わが国で聴覚障害児に積極的な聴覚活用が開始され てから 40 年あまりが経過した。補聴器による聴覚活用 の歴史は, 聴覚障害児者にとっての聴覚活用の意義を 明らかにするとともにその限界や活用方法について多 くの示唆を与えている. 近年新生児聴覚スクリーニン グ検査の開始と人工内耳の普及により, 聴覚活用はよ り早期化し, 最重度の聴覚障害児にも新たな可能性を 開くこととなった。しかしながら聴覚障害の影響の広 がりは大きく，年齢や環境によってもさまざまな課題 が出現する. 乳幼児期の聴覚活用も, 長期的視点に立 ち，その影響の拡がりを考慮しながらハビリテーショ ンに位置づけることが重要である。これらを踏まえ, まずは聴覚障害のない子ども（以下聴児）の聴覚およ びコミュニケーションと言語習得の関係について述 べ, 次に聴覚障害児に対する聴覚的アプローチの実際 からその意義と考え方について考察する.

\section{聴覚・コミュニケーション・言語習得}

一般に人間の存在にとって最も重要な感覚は視覚で あるといわれている。しかしながら Guttich ${ }^{1}$ が個人の 発達や人類の発達には「耳」は最も重要であると述べ ているように, 乳幼児期の子どもにとって聴覚は非常 に重要な感覚である。なぜなら聴覚は時間的・空間的 拡がりをもつ感覚であり, 環境との直接的接点をもつ 感覚であり，情動を摇さぶる感覚だからである。

人は常に社会的環境・自然環境の中にあり，それを キャッチするための身体と感覚を有している。そして みずからの身体や感覚を使い, 外部の世界と能動的な かかわり合い，すなわちコミュニケーションをしなが ら人や物, 環境のもつ意味を発見していく.そしてこ とばはそのようなコミュニケーションから生まれてく ると考えられる。

コミュニケーションは複雑なプロセスであるが，ア ダムソン ${ }^{2)}$ は, 乳幼児のコミュニケーションには, (1)人 と人との調和的統合を図るための「親交」, (2)情報のや り取りをする「伝達」，(3)その社会がもつ文化的意味, 人間的意味を学び取る「教育」の働きが含まれると述 べている。すなおち子どもは，コミュニケーション場 面で情動的な共有体験をべースにし，メッセージを伝 達し合い, さらにコミュニケーションパートナーとの 交流により，自分ではできないやり方を身につけてい く.つまりコミュニケーションの「場」は学習の「場」 であり, 子どもの学習にとってコミュニケーションパ
ートナーは「足場を掛ける」人としても重要な役割を 担っている.

中村雄二郎 ${ }^{31}$ は，「ことば」には理性の普遍性におい て人と人を結びつける「概念コミュニケーション」と， 感情の共同性に抢いて人と人を結びつける「イメージ コミュニケーション」を司る働きの両方があると述べ ている。つまりことばは, 高度に抽象化された記号で ある前に, 人間の感覚や身体の全体性とかかわる情動 やイメージに深く関与し，そのことばのもつ情動性や 感情性の共有が集団を支えていると指摘する。すなわ ちことばの機能には認識的・客観的機能と感情的・主 観的機能の二重の機能があるが，母語とは，このよう な情動性や感情性を深く内包した言語であることに大 きな意味があり，「言語は文化である」といわれるゆえ んでもある。したがって乳幼児期の言語習得の出発は 情動的なコミュニケーションを通した相互的関係性の 成立に求められるべきである。

\section{聴覚活用と言語習得}

\section{1．聴覚活用とは}

知覚心理学者 J.J. Gibson (1904-1979) は, 人は環境 が提供する情報の能動的知覚者であり, 耳とか目とい ったミクロな受容器ではなく, マクロに組織化された 身体によって知覚していると述べ, 知覚のために組織 化された身体を「知覚システム」と呼んだ4).

乳児は環境と持続的に繰り返し接触し，さまざまな 知覚システムの動作を洗練化している。佐々木出は, 「なかでも発話から意味を獲得する知覚システムは人 間が達成する知覚システムの中でも最も精緻なもので あり，したがって数年に及ぶ非常に長い時間をかけて そのスキルを身体化しなければならない」と述べてい る。すなわち聴覚活用とはそのような「能動的な聴く システム」を形成することにほかならない。「能動的な 聴くシステム」の形成には, (1)環境の中にある聴覚的 情報に共鳴し, 反応する身体や感情の動き, (2)その意 味を探るための注意機能や探索活動, (3)みずからが聴 覚情報の発信源となり, 呼応的関係をつくることなど が必要とされる。

聴覚活用の方法占としては，(1) discrete skill approach, (2) language-based approach がよく知ら れている(図 1)。前者は, 検出 $\rightarrow$ 弁別 $\rightarrow$ 識別 $\rightarrow$ 理解と 系列的に細分化された学習法である。これは中途失聴 者の人工内耳術後訓練などでの有効性はあるが，実際 の生活場面での情報の意味が見出しにくいため，子ど もには有効な指導法になりにくい。一方後者は言語学 


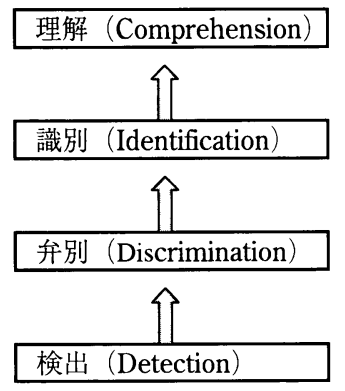

Discrete Skill Approach

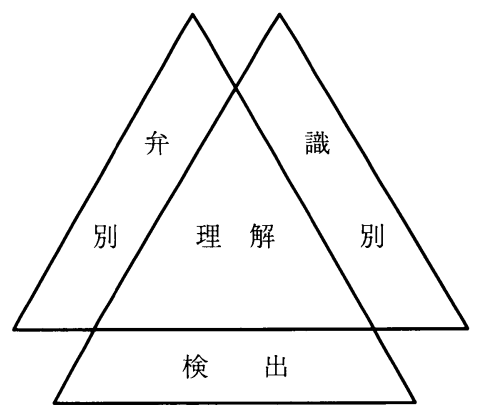

Language-based Approach
図 1 聴覚活用の方法 (Mischook $)^{5)}$

習を基盤に据えた方法であり，音の検出も弁別も識別 も子どもにとっての意味と結びつかなければ機能しな いという考え方である. 子どもにとっての意味とは， 実際の生活や遊びのなかで, 特にその子どもにとって 楽しい聴覚的経験の繰り返しによって生まれてくるも のである。ささら意味理解の成立には，入ってくる情 報を分析的に処理するボトムアップ的なプロセスと情 報を統合しトップダウンで処理するプロセスの両方が 必要であり，トップダウンとボトムアップの心的処理 の間にはたえず相互作用が生じている必要がある.

\section{2 . 言語習得と音声知覚}

一般に言語は, 音韻論, 形態論, 統語論からなる「形 式」と意味論からなる「内容」と語用論からなる「使 用」の 3 つの構成要素から定義される。そこで乳幼児 期の言語習得を考える際にも, 意味や語用といった「機 能」と「形式」から考えていく必要がある.

一般的な言語発達では, 1 歳前後に初語を迎え, 1 歳 半で 2 語文が出始め,「命名の洞察」とともに語彙の爆 発的増加が見られる.また 2 歳頃には大人との日常的 な会話が成立するようになり，語彙数も 200 語を数え る. 3 歳ではまだ文法的な言い誤りが多く見られるが， 4 歳になると文法的形態素はほとんど出揃う．5 歳頃 には多弁期を迎え，就学までには母語に関する基礎的 言語力を身につけ，語彙数も 3000 語を超える.

一方このような言語発達の基礎となる音声知覚の発 達については近年急速に研究が進んでいる. Werker ら ${ }^{6}$ の研究によると $6 \sim 8$ 力月児では常に新しい音素 連鎖に対する弁別的反応が可能だが，10〜12 力月児は 母語の意味的対立に依存した弁別様式に移行すること を明らかにした。すなわち普遍的音声知覚から言語に 特殊な音素知覚への移行はすでに生後 1 年目の後半に 見られる.さらに $\mathrm{Kuhl}^{7}$ は母音の識別能力について, (1)出生時：普遍的段階，(2) 6 力月：マグネット効果に よる母語の特化（あいまいな母音は記憶されている最
も近い母音に引き付けられる)，(3) 12 力月：母語に特 化した識別だけが可能，の 3 段階からなる「母語マグ ネット理論」を提唱している。

音声言語の特徵は音素と形態素からなる二重分節性 にあるが，乳児は発話の流れからどのようにそれらの 単位を切り出していくのだろうか. 正高8 ${ }^{8}$ は, 乳児には 生得的に協和音や子供向けの歌への選好傾向があり, 人の発話はまずメロディとして捉えられると述べてい る。そして聴覚的なまとまりの良さに基づくゲシュ夕 ルト知覚によって分節化を行っていると指摘してい る.たとえば文や節や句の境界近くでの音の変化が聴 覚的なまとまりの良さを生み出し, それがパターン知 覚を容易にする。すなわち日本の育児語に見られる擬 声語・擬態語の多用や助詞抜きの発話, 特徵的な強調 や繰り返しなどは聴覚的なパターン知覚を容易にし, 発話から語彙を切り出すうえで有効であり, 子どもの 言語習得を支える行動と考えられる。また擬声語・擬 態語の多くが身体の動きを伴わせやすく，それは意味 づけにおいても効果的である.

梶川ら9の語彙の分節化能力に関する一連の研究 は, 乳児はまずメロディ的側面の特徵を手掛かりに語 彙を記憶し, 次いで音素配列の記憶へと移行し, さら に音素配列に注目し出すとメロディの要素が切り捨て られていく過程を示しており, 興味深い.

さらに言語の本質は統語論にあるといわれように， 聴覚障害児の言語習得にとって文法習得と統語処理は

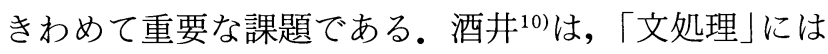
単語の意味処理だけではなく統語処理が必要であり, 統語処理から意味処理への情報の流れが重要であると 述べている. 通常文法習得は早期に開始され，その使 用の前に文法規則の理解が始まる。 また Johnson ら ${ }^{11)}$ の研究は母語と第 2 言語の境を決める文法習得の感受 性期が 7 歳頃にあることを示した。これをもってただ ちに母語の文法習得の感受性期と考えることはできな いが, 文法習得とその知覚処理過程の強い関連性を示 すデータとしても示唆に富むものである.

\section{聴覚障害児の音声言語習得上の課題と対応}

\section{1 。音声言語習得上の課題}

音声言語を習得し，それを有効に使いこなすために 必要な知覚処理には，少なくとも(1)超分節的処理，(2) 音韻処理，(3)文構造処理が必要である．聴覚障害児は いずれにおいても知覚処理上の課題を有する可能性が あり，それは音声言語習得上の課題ともなる。すなわ ち，(1)前言語的コミュニケーションの壁，(2)ことばの 


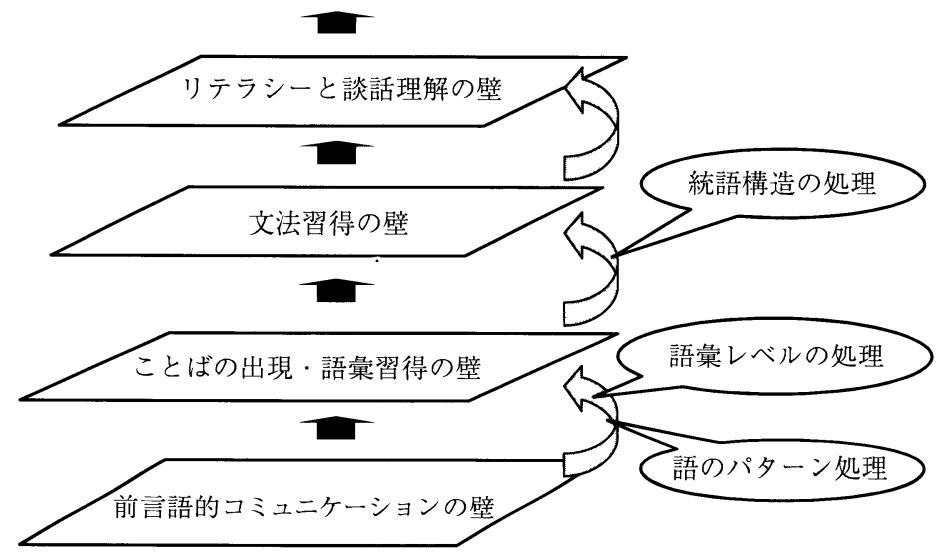

図 2 音声言語習得に必要な情報処理と聴覚障害児の音声言語 習得上の課題

出現・語彙習得の壁, (3)文法習得の壁, (4)リテラシー と談話理解の壁,である (図 2 ).

通常聴こえる子どもたちの各段階の発達の目安の時 期は, (1) 0 歳, (2) $1 \sim 2$ 歳, (3) 3 4 歳, (4) $6 \sim 10$ 歳で あるが，これらは成層的に積み重なっており，それに 必要な知覚処理はそれ以前にすでに可能になり始めて いる.たとえば初語は 1 歳前後であったとしても，そ の語彙の知覚的処理や語用論的理解はすでに前言語期 に始まっている．またこのような発達過程にとって重 要なことは各段階への移行がすみやかに進展すること であり，その背景にはそれに必要な知覚処理機能の関 与がある。つまりある段階の長期化は, そのレベルで の知覚の体制化や処理方略を習慣化させ，次の段階へ の変化を起こしにくくさせることに繋がるからであ る.

一方言語の創出と能動的な学習をもたらすために は, 子どもにとっての意味や機能性を高める必要があ る. そしてその背景には, 対人関係, 情動, 運動, 認 知, 社会性などの種々の学習や発達が関与し, それら は安定した環境と十分な時間が必要とされる。

\section{2. 前言語的段階の課題と対応}

やまだ12) は乳幼児期の基本的関係は「うたう」間柄で あり，「うたう」ことによるコミュニケーションは相互 の情動を伝染させるがごとく伝播し，直接的に相手の 気持と一体化できると述べている，そしてこの一体化 こそが初期の母子の愛着関係の形成を促進し，遅くと も 2 〜 3 月までにはこのような情動的響存関係が形 成されると主張している。この乳児期初期の「うたう」 関係は, 視線, 表情, 身体の動きなどさまざまな媒体 によって形成されるが，その最も基本的なものは音声 である.すなわち初期の聴覚一音声回路は, 情動の共
有を図り，注意の転換，拡大，維持など人と人とのコ ミュニケーションにとって重要な働きをしている。ま さに聴覚は, 注意を喚起し, 直接的に感情や状況を感 知する感覚であり，それによってコミュニケーション のチャンネルを開く感覚といえる。

しかしながら聴覚一音声回路に依存している聴者の 親と聴覚障害乳児との間では，互いに気持を合わせ， 共鳴し合い, 感情共有を図る情動的な相互的関係がう まく育たないことがある。なぜなら難聴の存在が，聴 者の親と聴覚障害乳児との間のコミュニケーション手 段の共有化を阻み，ごく初期に見られる発声による交 互作用の形成を困難にし，注意喚起や維持，注意対象 の共有化を制限するからであり，そのことが母子の愛 着関係の形成を阻害するからである。

したがって難聴の早期発見と早期ハビリテーション の開始の意義は, 言語習得をはじめとし, あらゆる発 達や学習の基盤となる養育者一乳児間の前言語的コミ ユニケーション関係の形成を支援することにある。す なわちまずは，(1)あらゆる感覚，特に視覚を積極的に 利用した前言語的コミュニケーションの成立，(2)愛着 関係を基盤にした聴覚一音声回路の形成，(3)相互的関 係性の形成が重要課題となる。この段階では子どもの 関心や注意対象にパートナーが合わせ，子どものやり 方やプロセスを尊重することが重要である，その過程 のなかで子どもは, 関係性の認識に有効な感覚の使い 方を身に付けていく，なかでも視覚を利用して相互交 涉活動やコミュニケーションモードへの感受性を高め ることが，聴覚活用の基盤を形成する。

また聴覚音声回路の形成は音声言語創出の重要な要 件である。一般に聴こえる乳児は生後 2 力月ほどでク ーイングといわれる発声が見られる。乳児の発声に対 


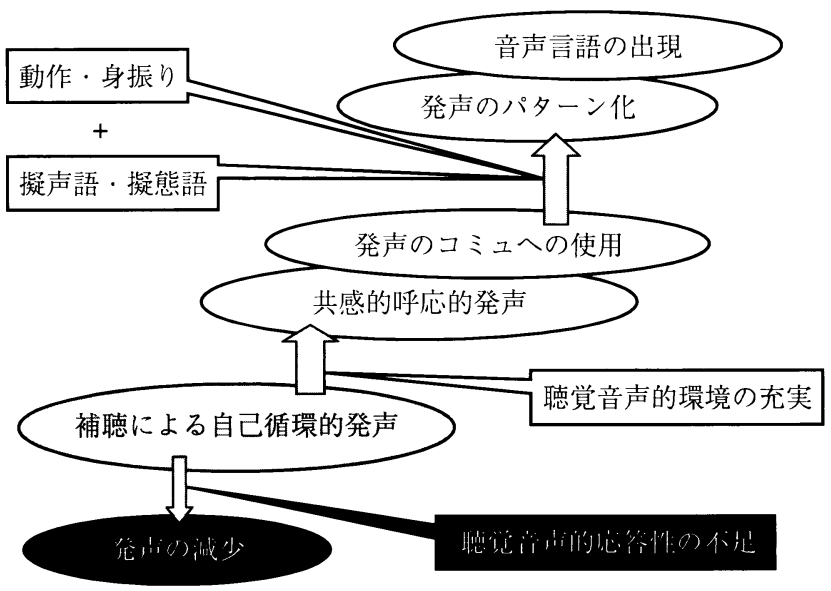

図 3 発声から音声言語への変化過程 相互的関係性と聴覚音声的環境の充実を基盤にした移行.

し声で応えると乳児は発声をやめ，傾聴したり，さら に引き続いて発声を繰り返すなど発声による呼応的な やりとりが見られるようになる。

聴覚障害乳児においても補聴器を装用し，十分なゲ インを補償するとそれによって自己循環的な発声が引 き出される。しかしながら自己循環的な発声は特に強 化をしないままでいると, 一定期間を過ぎると減少し, コミュニケーションの利用にいたらないまま消滅する ことがある。そこで自己循環的な発声に対し，子ども の視線をしっかり捉えながら発声で応えるなど十分な 聴覚一音声フィードバックを加えていくと，引き続い て発声は共感的な発声や要求発声として有意味化し, 移行の進展を促進する（図 3 ).

次に意図的発声が音声言語化するためには，一定の 音声パターンが形成され有意味化する必要がある。こ の段階では，擬声語・擬態語などのパターン発声に身 振りや動作などの身体的運動や視覚的手掛かりを加え て楽しく有意味な聴取を繰り返し重ねることが重要で ある。能動的な聴取によって形式と機能が結合し，そ れが発声のパターン化と有意味化を促し, 言語化を促 進する。

なおこの時点でコミュニケーションパートナーは鋭 敏な応答者であることが重要である，子どものかすか な表現や身体的活動を受け止め, 非音声的表現に対し ても絶えず聴覚音声的フィードバックを「見える形」 で豊富に繰り返し，ともに楽しみ，子どもの注意対象 となり続けることが必要である。コミュニケーション パートナーのこのような対応が，相互的関係の形成を 促し，能動的な聴取を実現する基盤となる。そして十 分な聴取経験が発声の習慣化とコントロールに繋が

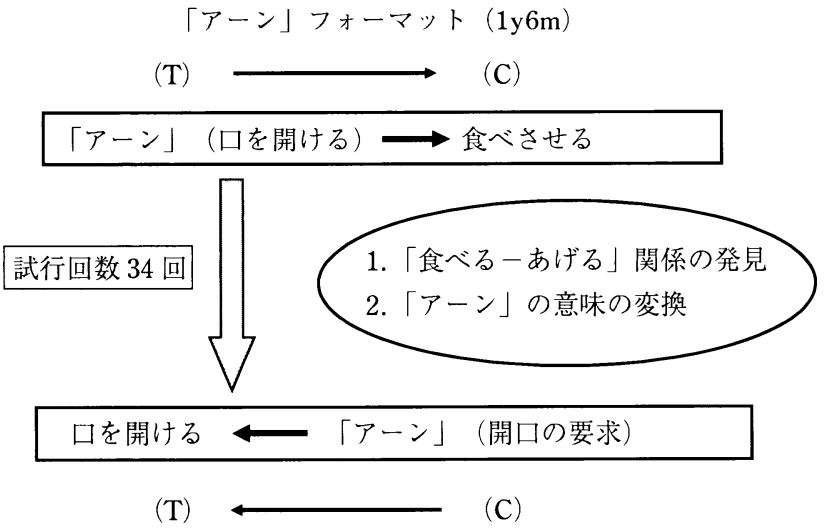

図 4 プレイ場面での相互交涉活動を通した言語学習過程 動物の手人形に食べ物をあげる遊び，指導者 Tが「アーン」と いいながら口を開けると, 子どもCがミニチュアの食べ物を食 べさせる．繰り返すうちに子どもが自ら「アーン」と発声し， 口を開けることを要求する。

\section{3. 語彙習得段階の課題と対応}

通常乳児は 1 歳前後に初語を迎えるが, Nelson ${ }^{13}$ は 「真の初語」は 10 語に達する時期とし, 言語発達の安 定した指標としている. 1 2 歳で発見された重度聴 覚障害児の語彙習得過程においても最初の 10 語の習 得に時間を要し,次の 10 語はその $1 / 2$ 以下に短縮され る ${ }^{14)}$. さらに $20 \sim 30$ 語の習得段階で音声模倣が活発化 し，30 語を過ぎると 2 語発話が出現するなど，表面的 には聴児の経過と類似している．聴児においてはその 後語彙の爆発的増加の時期を迎えるが聴覚障害児にお いては個人差が大きい。この段階で重要なことは，(1) 単語の聴覚像の形成，(2)体験的意味の形成である. 多 くの研究者がことばの覚え初めの「沈黙の時期」の重 要性を述べているように ${ }^{15)}$, 聴覚障害児においても発 話を無理強いせずに，ことばの聴覚的経験を十分に与 えられることが必要である。恥覚障害は「入力」の障 害である。したがって聴児以上にていねいな聴覚経験 を積み重ねる必要がある。この沈黙しながら傾聴する 過程のなかで，子どもはその形式的な特徵の記憶やそ の意味や機能の発見を実現している。図 4 は聴覚障害 児 (1 歳 6 カ月, 両耳 $90 \mathrm{~dB})$ が遊びのなかで聴取を繰 り返した後，自発使用する過程であるが，同じフォー マットのやり取りを 34 回，30 分以上継続している.

これらは楽しい遊び場面での子どもの主体的な活動 が実現の原動力になっている。このような繰り返しは 語の形式を明確にするだけでなく，機能性を高めると ともに，語への情動的な意味やイメージの付与に役立 つ. る。 


\section{4. 文法習得段階の課題と対応}

一般に文の意味理解の手掛かりとして，(1)語と統語 構造に関する知識, (2)言語的文脈, (3)非言語的文脈, (4)外界に関する知識などが必要とされる ${ }^{16)}$. しかしな がら実際の場面では，いくつかの手掛かりになる語が 聴き取れれば統語構造が処理できなくとも文脈によっ て意味の推測が可能になることが多い.しかしながら そのような方略を続けていると文レベルの処理に移行 しないまま単語処理段階にとどまることになる，聴覚 障害児に見られる文法習得の壁の大きな原因の一つ は, この単語処理レベルから統語処理レベルへのすみ

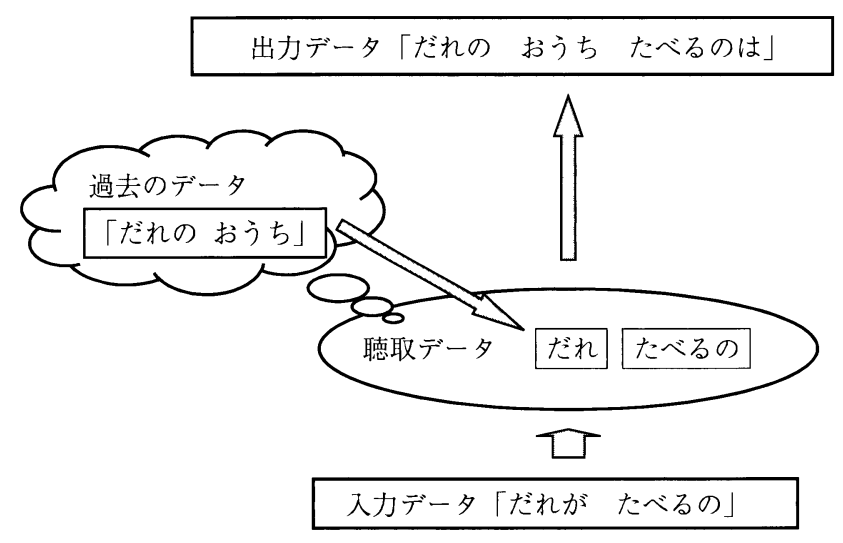

図 5 推定される復唱の機序

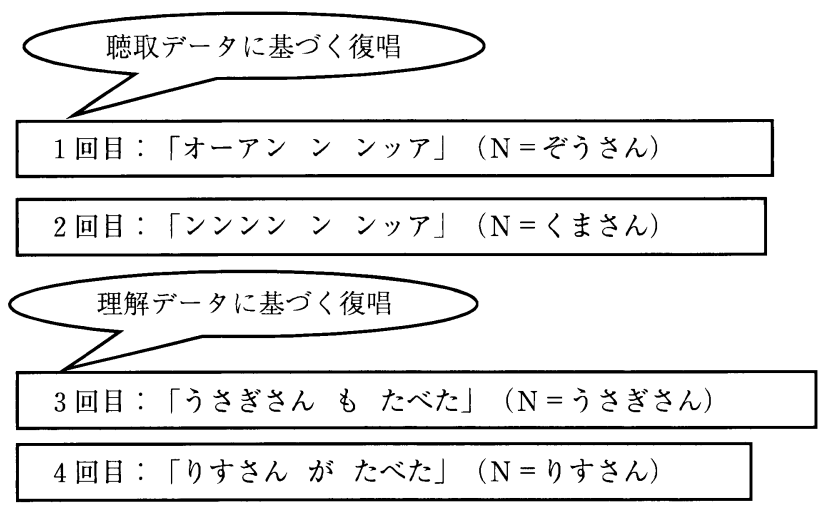

図 6 復唱の変化過程：「Nがたべた」
やかな移行の失敗にある。

聴覚障害児のなかには，状況文脈と聴き取れたいく つかの単語や常套的な文を手掛かりにした処理方略の まま就学を迎える例もまれではない，そのような子ど もたちは，(1)単語の羅列的表現が多い，(2)相手の話を 最後まで聴かずに一部を聴いて応答する，(3)脱状況下 での文レベルでの理解が困難，(4)一方的に話すなどの 特徴を示す。

統語構造の習得の過程では, 文の構成要素すべての 知覚と文法的解剖が必要である。しかしながら聴覚障 害児においては通常のコミュニケーション状況では構 成要素の正確な知覚の確保が困難なため, 継時的に入 力される文の統語構造を瞬時に処理する構造的な知覚 処理過程が進展しにくい.そこで文レ心゙ルでのていね いな反復聴取が必要とされる。筆者は統語構造の聴取 を促すために, 同じ構文が繰り返される絵本を作成し， 聴取教材として用いている ${ }^{17)}$.その経験から文の聴覚 的処理について $2 つ の$ 事例を紹介する。

症例 $\mathrm{A}$ は聴覚口話的指導を実施した重度難聴例であ る. 平均聴力レベル右耳 $107 \mathrm{~dB}$, 左耳 $116 \mathrm{~dB}$, 難聴の 診断 11 力月, 補聴器装用 1 歳であった. 4 歳 0 力月時 点では読話併用で日常レベルの会話がかなり成立す る.目標構文は「だれがたべるの?」「〜がたべる」で あり，絵を見ながら聴覚のみでテープから一文ずつ聴 取し, 復唱する課題である。その後指導者も復唱し, 読話併用による聴取内容の強化を図った。このお話に は「だれがたべるの？」という文が 4 回出てくるが， 1 回目は「だれの」, 2 回目は「だれのおうち たべる のは」となり，3〜 4 回目で正しく復唱されている. 図 5 は 2 回目の復唱の機序の考察である.入力デー夕は 「だれが たべるの」だが正しく聴取することは困難で あったと思われる。そこでかろうじて聴取できた「だ れ」を以前利用したお話の構文「だれのおうち?」と 同定し, 復唱している.すなわち聴取された音像の解 読に過去のデータを参照したことが推測される。

表 1 手話構文の影響例

\begin{tabular}{|c|c|c|}
\hline & 内容 & 例 \\
\hline 1 & 語順の倒置 & $\begin{array}{l}\text { 例 } 1 \text { ：「かばん あか」 } \\
\text { 例 } 2 \text { :「を なにしてる」(復唱時) }\end{array}$ \\
\hline 2 & 助詞の脱落(1) & $\begin{array}{c}\text { 単語の羅列的表現の継続 } \\
\text { 例 } 3 \text { :「パパ } \text { かいしゃ } い く ~\end{array}$ \\
\hline 3 & 助詞の脱落(2) & 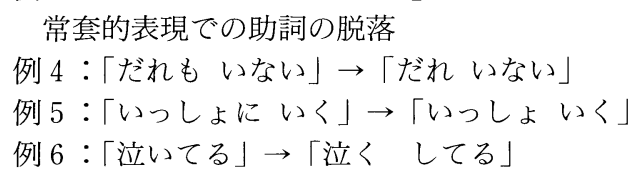 \\
\hline
\end{tabular}


また「Nがたべた」という文では，1，2 回目は文全 体のイントネーションをほぼ音節対応で復唱しており (図 6 ), 聴取デー夕に基づく復唱が見られた。しかし ながら徐々にその構造や内容が理解されてくると, 理 解デー夕を加味し, 正しく復唱できるょうになった。 すなわちこれらの復唱結果はボトムアップとトップダ ウンの両方の処理方略を示していると考えられる.

聴覚障害児の聴覚活用ではよく「脳で聴く」といわ れるようにトップダウン処理の向上が重要視されてい る.高度で豊かなトップダウン処理を可能にするには， ていねいに聴取経験を積み重ね，ボトムアップ処理の 向上を図ることが重要である。したがって乳幼児期の ひたすらに聴く時期に文の構造的聴取を可能にするこ とが重要である。その結果として日本語の統語処理が 実現したときに，聴覚障害児にとっても有効な音声処 理のための聴覚活用が実現することになる.

また統語処理は知覚レベルにのみ依存するものでな い. 症例 $\mathrm{B}$ は平均聴力レベル左右とも $70 \mathrm{~dB}$ の壟家族 の子どもである. 難聴診断は 1 歳 1 力月, 3 歳時には父 母姉には手話で，聴者には口話でと使い分けが見られ た。単語レベルの聴覚活用は良好で発話明瞭度も高い が，本児の発話には表 1 に見られるように多くの手話 構文の影響が見られた。特に例 2 「なにをしてる」と 「を」を強調すると，「を，なにしてる」と復唱する語 順倒置, 例 4,5 の常套的文表現での助詞の脱落, ま たは例 6 「泣いてる」を「泣くしてる」とする「語 の原型+スル」などの発話例は, 聴覚活用をしている 中等度難聴児にはあまり見られない。

B 児 (4 歳 1 力月) の文の聴取を，日本語構文を主に 担う格助詞とそれ以外に分けて調べた。2〜 3 文節文の 短文であるが，助詞以外の聴取率が $97 \%$ に対し，助詞 6\%とほとんどが脱落し, 改善の速度も遅かった。一方 A 児は重度難聴にもかかわらず，同条件下で初回でも 40\%聴取でき， 1 週間後には $100 \%$ となった（図 7 ）。 この事実は，B児が 4 歳の時点ですでに手話文法を利 用した音声言語処理をしている可能性を推測させる. すなわちこれは統語構造処理が入力モダリティに依存 するものではないことを示唆している ${ }^{10)}$ 。なお B児も 構文聴取指導を継続することで 2 年後には助詞の聴取 率は $94 \%$ と向上し, 適切な助詞の使用が見られ, 不自 然な語順の倒置や語形も見られなくなった（図 8 ).

次に人工内耳症例の文の聴取能についてである，表 2 は術時年齢 $3 \sim 4$ 歳 5 症例の $8 \sim 10$ 歳時点での聴取 結果である. CI 2004 の学童用の文を CD から聴取さ せた。助詞もそれ以外も5名ともほぼ100\%であり, 良

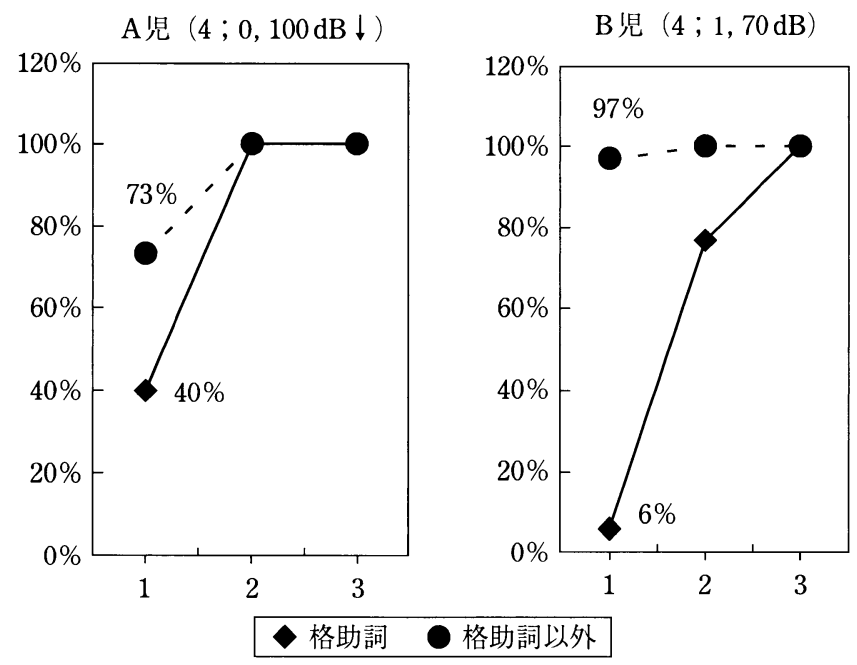

図 7 短文（ $2 \sim 3$ 文節文）での構文聴取力の比較 補聴器装用経験 3 年, テープから聴覚のみでの聴取結果.

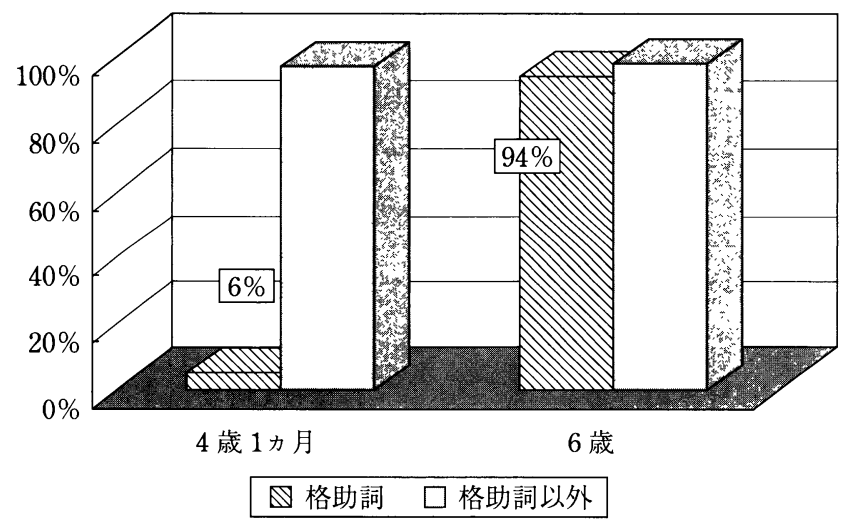

図 8 B児における構文聴取力の変化 4 歳児： $2 \sim 3$ 文節文, 6 歳児： $3 \sim 5$ 文節文

表 2 人工内耳装用児 5 例の構文聴取力

\begin{tabular}{ccc}
\hline & 助詞 & 助詞以外 \\
\hline 1 & $97 \%$ & $94 \%$ \\
2 & $97 \%$ & $96 \%$ \\
3 & $94 \%$ & $94 \%$ \\
4 & $97 \%$ & $94 \%$ \\
5 & $97 \%$ & $98 \%$ \\
\hline \multicolumn{3}{c}{ (CI 2004, 学童用文, CD 使用) }
\end{tabular}

好な聴取成績を示している.

しかしながら小児の人工内耳例が増えるにつれ，十 分な聴覚活用がされず，言語力も不十分なまま就学を 迎える例も散見する. 図 9 は 3 例の人工内耳症例の就 学時段階での聴取結果 (肉声) である. 術時年齢 $2 \sim 3$ 歳で音入れ後 $3 \sim 4$ 年が経過している. C 児は助詞の 聴取率 $88 \%$ と助詞以外の聴取と大きな差はないが, D 児, $\mathrm{E}$ 児の 2 例は助詞の脱落や聴き違いが多く, 文レ 


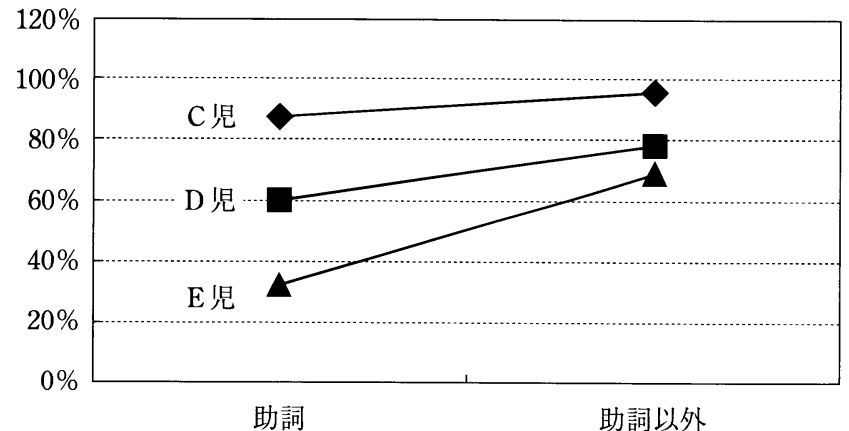

図 9 人工内耳装用児 3 例の構文聴取力（ $2 \sim 4$ 文節文 $)$

ベルでの聴取の困難さが窅える.

人工内耳における聴覚活用も個人差が大きいが, 術 前と比べ格段に聴覚的反応が向上するため, 周囲の人 は「よく聴こえている」と思いがちである。しかしな がら聴覚活用は聴覚的環境にいるだけでは実現しな い. また単語や単語の羅列, 簡単な常套的文で話がで きることと，十分な統語処理に基づいた言語使用とは 異なる. 言語の知覚的処理方略の形成過程が語や文の 意味や使用と絶えず相互的不可分に学習されるよう系 統的な評価と指導が必要とされる。

\section{5.リテラシーの形成}

一般に聴こえる子どもは生活のことばとして音声言 語を習得したうえで，それを基に書記言語の世界に入 っていく。しかしながら書記言語は話し言葉とはまた 異なった構造をもっており, リテラシー形成は学童期 の大きな課題である。一方聴覚障害児にとってリテラ シーの習得はコミュニケーション手段としても言語習 得手段としても重要であり, 幼児期から積極的に導入 されている。しかしながら早期に組織的に導入される ものの, その習熟度は個人差が大きく, 語彙や文法力 などの言語力との関連性が指摘されている ${ }^{18)}$. また読 解などの文章理解は, 文字言語からの刺激だけに依存 しているわけではなく, 外界や言語に関する知識との 相互作用によって能動的に作り出される. したがって 関連知識の活性化を図り, その整合性を吟味する過程 が不可欠となる，つまりそれらを容易にする要因の一 つはことばに内包される豊富なイメージとそれに基づ くことばのネットワークにある.

すなわち音声言語でも文字言語でもそのモダリティ に対応した語彙や統語に関する知覚レベルの処理と意 味の連合を図るだけでは十分な理解力や表現力, 思考 力を形成し，自己のアイデンティティに繋がる「言語」 とはならない.「母語」は単なる記号ではない. 話され たことばや書かれたことばへの理解力は, そのことば
の発せられた奥深くをその表現形式や文脈や状況から 推察し, 洞察する力や共感する力と関係する. 言語学 習とは，まずことばに“個人的意味やイメージ”を付 与しつつ一般的意味へと変容する過程である.このよ うな学習過程のなかで, 子どもはみずから形式と意味 との関係を状況に照合しながら幾重にも塗り替えてい く.それらの学習過程の集積が，イメージの共有化を 図り, 表現されたことばへの理解力を高め, ことばの もつ抽象性やあいまい性の有効利用を促す。したがっ て音声言語習得は, 子ども自身の生活の場における豊 かなコミュニケーションの場で，体験的意味やイメー ジの形成を図りながら, 聴覚的処理ルートの形成を実 現していくことが重要であると考える。

\section{ま と め}

聴覚障害児の聴覚活用と言語習得について, 正常発 達の知見を参照しながらその意義, 課題と対応につい て報告した。聴覚障害児の聴覚活用とは，コミュニケ ーション場面での意味ある聴覚的経験を通して「能動 的な聴くシステム」を形成することである.しかしな がら実際のコミュニケーション場面で不十分な聴知覚 を活用するためには, 状況への注意能力や洞察力, 類 推力やコミュニケーション意図への優れた感受性や読 話力が必要とされる。すなわち聴覚を十分活用するた めには他の感覚, 特に視覚を十分活用することが重要 である.「よく見る子」に育てることが，「よく聴く子」 に育つことであり，「聴覚的世界の拡がり」が「よく見 る子」への足掛かりにもなる. 聴覚障害児にとって聴 覚を活用することは多くの困難が伴うことを忘れては ならない.したがって障害のある聴覚を活用するには, 早期に, コミュニケーションを通して, 楽しく, 有意 味にすることが主体的・能動的な学習を実現する条件 である.さらに聴覚活用の限界も認識し, 子どもに応 じた適切なモダリティ選択や対応をとることが肝要で ある。

\section{文献}

1) Guttich A: Neurologie des Ohrlabyrinths, Neurology of the Labyrinth, Leipzig, 1944.

2）アダムソン RB：乳児のコミュニケーション発達 ことば が獲得されるまで, 川島書店, 16-39 頁, 1999.

3）中村雄二郎: 共通感覚論一知の組みかえのために一, 岩波 書店, 1979 .

4）佐々木正人：アフォーダンス 新しい認知の理論, 岩波書 店, 110-111 頁, 1994 .

5) Mischook M：聴覚学習と聴覚障害幼児の指導. 聴觉障害 (コールE, 他編著, 今井秀雄訳), コレール社, 107-129 頁, 
1990.

6) Werker J and Tess R: Cross-language speech perception: Evidence for perceptual reorganization during the first year of life. Infant Behavior and Development, 7: 49-63, 1984.

7) Kuhl PK: Learning and representation in speech and language. Current Opinion in Neurobiology, 4: 812-822, 1994.

8）正高信男：子どもはことばをからだで覚える，中公新書， 2001.

9）梶川祥世，正高信男：前言語期における乳児の語彙に関す る分節化能力. 認知科学, $7: 131-138,2000$.

10）酒井那嘉：言語の脳科学, 中公新書, 2002 .

11) Johnson JS and Newport EL: Critical period effct in second language learning: The influence of maturational state on the acquisition of English as a second language. Cognitive Psych, 21: 60-99, 1989.

12）やまだようこ：ことばの前のことば，新曜社， 1978.
13) Nelson K: Structure and strategies in learning to talk. Monographs of the Society for Research in Child Development, 38(149): 1973.

14）中村公枝：難聴乳幼児の治療教育，難聴乳幼児指導の手引 き（田中美郷編著），平成 2-4 年厚生省心身障害研究「治療 教育の開発と統合化に関する研究，93-149 頁，1993.

15）Winitz H：構音訓練における聴覚に関する検討. 構音障害 の言語治療 (Winitz $\mathrm{H}$ 編著), 協同医書出版社, 21-44 頁, 1993.

16）デイル PS：言語発達，新曜社， 1983.

17）中村公枝：第 3 章 高度・重度難聴乳幼児の指導. アドバン スシリーズコミュニケーション障害の臨床, 聴覚障害, 協 同医書出版社, 107-139 頁, 2002.

18）齋藤佐和：コミュニケーション方法とリテラシー形成（特 別発言)。音声言語医学, $47: 332-335,2006$.

別刷請求先： 